\title{
Arcanobacterium bialowiezense sp. nov. and Arcanobacterium bonasi sp. nov., isolated from the prepuce of European bison bulls (Bison bonasus) suffering from balanoposthitis, and emended description of the genus Arcanobacterium Collins et al. 1983
}

Correspondence

Stephanie Speck speck@izw-berlin.de

\author{
Alexandra Lehnen, ${ }^{1}$ Hans-Jürgen Busse, ${ }^{2}$ Kai Frölich, ${ }^{1}$ \\ Malgorzata Krasinska, ${ }^{3}$ Peter Kämpfer ${ }^{4}$ and Stephanie Speck ${ }^{1}$ \\ ${ }^{1}$ Institut für Zoo- und Wildtierforschung, Alfred-Kowalke-Str.17, D-10315 Berlin, Germany \\ ${ }^{2}$ Institut für Bakteriologie, Mykologie und Hygiene, Veterinärmedizinische Universität, \\ Veterinärplatz 1, 1210 Wien, Austria \\ ${ }^{3}$ Mammal Research Institute PAS, ul. Waszkiewicza 1c, 17-230 Bialowieza, Poland \\ ${ }^{4}$ Institut für Angewandte Mikrobiologie, Justus-Liebig-Universität, Heinrich Buff-Ring 26-32 \\ (IFZ), D-35392 Giessen, Germany
}

Since 1980, a chronic disease of the external genital organs of male European bison (Bison bonasus) has been observed on the Polish side of the Bialowieza Forest (Kita et al., 1994).

Published online ahead of print on 25 November 2005 as DOI 10.1099/ijs.0.63923-0.

The GenBank/EMBL/DDBJ accession numbers for the 16S rRNA gene sequences of strains $1(\mathrm{~W} 3 / 01)^{\top}$ and $2(\mathrm{~W} 106 / 04)^{\top}$ are AJ879696 and AJ879697, respectively.

The polar lipid profile of strain $1(\mathrm{~W} 3 / 01)^{\top}$ is available as a supplementary figure in IJSEM Online.
The advanced stage of the disease is characterized by oedema of the skin surrounding the preputial orifice and accumulation of thick exudate and necrotic tissue within the preputial cavity (Jakob et al., 2000).

In the course of a study concerning the aetiological agent of the balanoposthitis, several bacterial strains were isolated. Based on preliminary classification, these isolates were identified as members of the genera Arcanobacterium, Corynebacterium, Bacillus, Fusobacterium, Peptostreptococcus, Prevotella, Staphylococcus and Streptococcus and the family 
Enterobacteriaceae (A. Lehnen, unpublished results). Thirteen strains isolated from the prepuces of 13 European bison bulls suffering from balanoposthitis [strains $1(\mathrm{~W} 3 / 01)^{\mathrm{T}}$, 1(W10/02), 1(W89/03), 1(W91/04), 2(W106/04) $)^{\mathrm{T}}, 2(\mathrm{~W} 4 / 01)$, 2(W34/02), 2(W76/03), 2(W78/03), 2(W87/03), 2(W101/04), 2 (W103/04) and 2(W105/04)] were found to be morphologically similar to Arcanobacterium pyogenes, but could not be identified by standard diagnostic tests. Although these strains were isolated exclusively from bulls with balanoposthitis, their pathological significance is still unknown. However, the phylogenetic relationship to A. pyogenes underlines their possible role in the aetiology of balanoposthitis. In order to clarify the taxonomic status of this set of isolates, the strains were characterized by a combination of genomic, physiological and chemotaxonomic methods.

\section{Genomic analyses}

Based on almost identical genomic fingerprints generated after BOX-PCR according to the method described by Louws et al. (1994), the Arcanobacterium isolates were grouped into two clusters and each cluster was assumed to represent a distinct species. Strains $1(\mathrm{~W} 3 / 01)^{\mathrm{T}}$ and $2(\mathrm{~W} 106 / 04)^{\mathrm{T}}$ were selected as representative strains from each of the clusters. Cluster I, represented by strain $1(\mathrm{~W} 3 / 01)^{\mathrm{T}}$, exhibited four predominant bands, with sizes of approximately 450, 550, 750 and $1500 \mathrm{bp}$. Cluster II, represented by strain 2(W106/ $04)^{\mathrm{T}}$, exhibited three predominant bands, with sizes of approximately 550, 850 and $1100 \mathrm{bp}$. A. pyogenes DSM $20630^{\mathrm{T}}$ exhibited a distinct BOX fingerprint (Fig. 1).

$16 \mathrm{~S}$ rRNA gene amplification was performed according to Wyss et al. (1996). Amplified PCR products were sequenced bidirectionally using an ABI 3100 Genetic Analyzer (Applied Biosystems). The resulting $16 \mathrm{~S}$ rRNA gene sequences of strains $1(\mathrm{~W} 3 / 01)^{\mathrm{T}}$ and $2(\mathrm{~W} 106 / 04)^{\mathrm{T}}$ consisted of 1481 [positions 36-1517, Escherichia coli numbering (Brosius et al., 1978) ] and 1444 nucleotides (36-1480, E. coli numbering), respectively. In a FASTA search (Pearson \& Lipman, 1988), the two isolates shared $97 \cdot 2 \%$ gene sequence similarity. Isolates $1(\mathrm{~W} 3 / 01)^{\mathrm{T}}$ and $2(\mathrm{~W} 106 / 04)^{\mathrm{T}}$ exhibited highest sequence similarities to A. pyogenes DSM $20630^{\mathrm{T}}$ (96.1 and $96 \cdot 4 \%$, respectively) and Arcanobacterium bernardiae DSM $9152^{\mathrm{T}}(95 \cdot 5$ and $95.8 \%$, respectively). Sequence similarities with other species of Arcanobacterium were in the range $93 \cdot 3-94 \cdot 7 \%$. These results indicate that strains $1(\mathrm{~W} 3 / 01)^{\mathrm{T}}$ and $2(\mathrm{~W} 106 / 04)^{\mathrm{T}}$ are affiliated to the genus Arcanobacterium, but are not members of an established species. In order to display the phylogenetic relationships of the two representative strains with established species of the genus Arcanobacterium, a dendrogram was constructed after multiple alignment with publicly available 16S rRNA gene sequences using MEGA version 2.1 (Kumar et al., 2001). The results clearly demonstrated that the two isolates are closely related and that they are located on the Arcanobacterium lineage (Fig. 2), with A. pyogenes DSM $20630^{\mathrm{T}}$ and A. bernardiae DSM $9152^{\mathrm{T}}$ as the closest related species.

DNA-DNA hybridizations (Ziemke et al., 1998; Kämpfer et al., 2003) between strains $1(\mathrm{~W} 3 / 01)^{\mathrm{T}}$ and $2(\mathrm{~W} 106 / 04)^{\mathrm{T}}$ revealed a DNA-DNA relatedness of only $9 \cdot 4 \%$ (reciprocal $13 \cdot 2 \%)$. This low value unambiguously demonstrated that strains $1(\mathrm{~W} 3 / 01)^{\mathrm{T}}$ and $2(\mathrm{~W} 106 / 04)^{\mathrm{T}}$ are representatives of two separate species.

\section{Biochemical characteristics}

An investigation of A. bernardiae DSM $9152^{\mathrm{T}}$, Arcanobacterium haemolyticum DSM $20595^{\mathrm{T}}$, Arcanobacterium hippocoleae DSM $15539^{\mathrm{T}}$, Arcanobacterium pluranimalium DSM $13483^{\mathrm{T}}$, Arcanobacterium phocae DSM $10002^{\mathrm{T}}$, A. pyogenes DSM $20630^{\mathrm{T}}$ and strains $1(\mathrm{~W} 3 / 01)^{\mathrm{T}}$ and $2(\mathrm{~W} 106 / 04)^{\mathrm{T}}$ using commercially available API Coryne, API CH50 and API ZYM tests (bioMérieux) revealed metabolic profiles that were distinct for each strain (Table 1). The other isolates which, based on BOX band patterns, had been grouped with strain $1(\mathrm{~W} 3 / 01)^{\mathrm{T}}$ [strains $1(\mathrm{~W} 10 / 02), 1(\mathrm{~W} 89 / 03)$ and $\left.1(\mathrm{~W} 91 / 04)\right]$ or strain 2(W106/04) ${ }^{\mathrm{T}}$ [strains 2(W4/01), 2(W34/02), 2(W76/ 03), 2(W78/03), 2(W87/03), 2(W101/04), 2(W103/04) and 2 (W105/04)] showed profiles which were almost indistinguishable from the selected representative of each cluster. The two similarity groups could be distinguished from one another by their biochemical profiles, confirming that each group represents a distinct species. Gram-staining (Quinn et al., 2000) of cells of the two novel isolates revealed Gram-positive behaviour. Isolates $1(\mathrm{~W} 3 / 01)^{\mathrm{T}}$ and $2(\mathrm{~W} 106 / 04)^{\mathrm{T}}$ were catalase- and oxidase-negative, showed no serolysis on Löffler serum agar and no growth on Gassner or MacConkey agar. The optimum growth temperature on sheep blood agar was $37^{\circ} \mathrm{C}$. No growth occurred at $42{ }^{\circ} \mathrm{C}$. The best growth occurred under aerobic conditions. Growth in a $\mathrm{CO}_{2}$-enriched $\left(\mathrm{CO}_{2} \mathrm{Gen}\right)$ or anaerobic atmosphere (AnaeroGen) was slowed. Other characteristics are listed in the species descriptions and in Table 1.

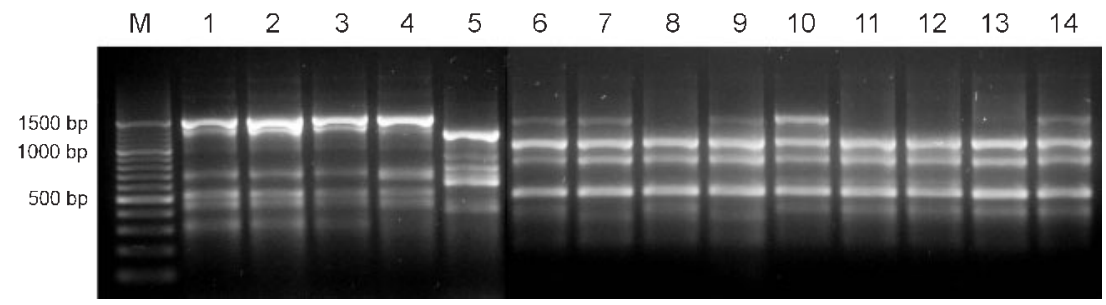

Fig. 1. BOX-PCR-generated fingerprints of the Arcanobacterium isolates. Lanes: M, $100 \mathrm{bp}$ standard marker; $1,1(\mathrm{~W} 3 / 01)^{\mathrm{T}} ; 2$, 1(W10/02); 3, 1(W89/04); 4, 1(W91/04); 5, Arcanobacterium pyogenes DSM 20630'; 6, 2(W106/04) $)^{\top} ; 7,2(\mathrm{~W} 4 / 01) ; 8,2(\mathrm{~W} 34 / 02)$; 9, 2(W76/03); 10, 2(W78/03); 11, 2(W87/ 03); 12, 2(W101/04); 13, 2(W103/04); 14, 2(W105/04). 


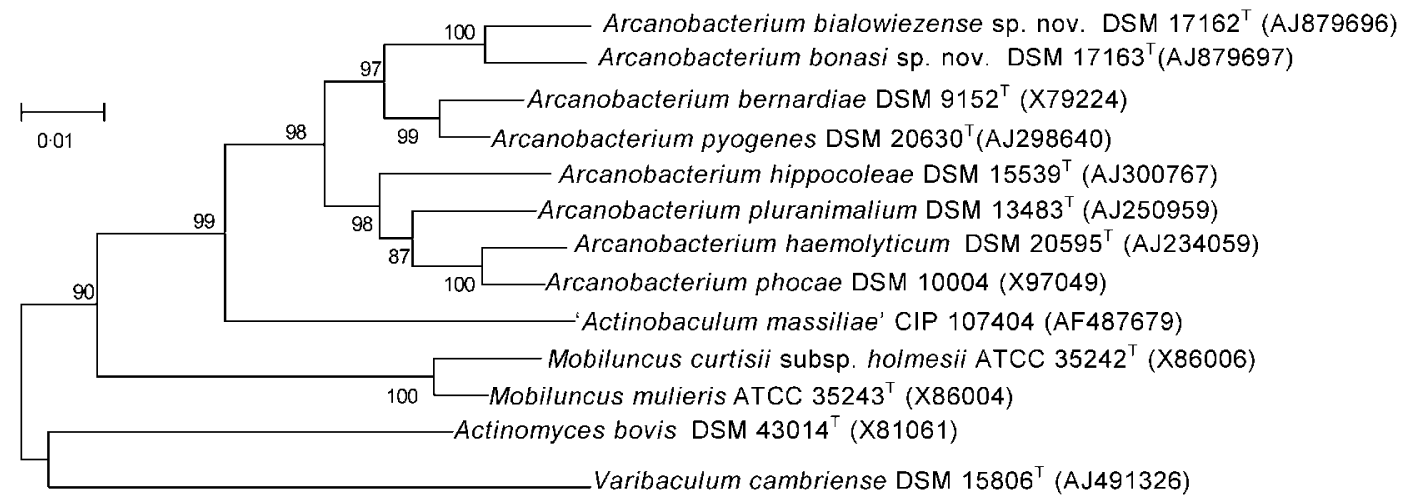

Fig. 2. Neighbour-joining dendrogram based on $16 \mathrm{~S}$ rRNA gene sequences showing the phylogenetic relationships of Arcanobacterium species and related genera. The dendrogram was constructed after multiple alignment of data using MEGA version 2.1 (Kumar et al., 2001). Bootstrap values based on 500 replications are given at branch points. Bar, 0.01 substitutions per nucleotide position.

\section{Chemotaxonomic characteristics}

Biomass for fatty acid, quinone and polar lipid analysis was collected from blood agar and washed twice with $0.9 \% \mathrm{NaCl}$ solution. Fatty acid analysis was conducted as described by Kämpfer \& Kroppenstedt (1996). The fatty acid profiles of the representatives of each BOX similarity group, strains $1(\mathrm{~W} 3 / 01)^{\mathrm{T}}, 1(\mathrm{~W} 10 / 02), 2(\mathrm{~W} 106 / 04)^{\mathrm{T}}$ and $2(\mathrm{~W} 34 / 02)$, as well as A. haemolyticum DSM $20595^{\mathrm{T}}$ and A. pyogenes DSM $20630^{\mathrm{T}}$, consisted predominantly of unbranched acids ( $>98 \%$ ). The six strains shared the presence of the major components $\mathrm{C}_{16: 0}, \mathrm{C}_{18: 1} \omega 9 \mathrm{c}$ and $\mathrm{C}_{18: 0}$ which was in good agreement with the profiles of $A$. pyogenes and A. haemolyticum as reported by Bernard et al. (1991). The fatty acid profiles distinguished the representatives of the two BOX similarity groups by revealing significant differences in the relative amounts of $\mathrm{C}_{14: 0}, \mathrm{C}_{18: 1} \omega 9 c, \mathrm{C}_{18: 1} \omega 6 c, \mathrm{C}_{16: 0}$ and/or $\mathrm{C}_{18: 0}$ (Table 2) and also distinguished them from the two reference strains.

Polar lipids were analysed as described by Ventosa et al. (1993). The polar lipid profiles of strains $1(\mathrm{~W} 3 / 01)^{\mathrm{T}}$ (see Supplementary Fig. S1 in IJSEM Online) and 2(W106/04) ${ }^{\mathrm{T}}$ were rather complex. Both strains contained diphosphatidylglycerol, phosphatidylglycerol, three unknown phosphoglycolipids, an unknown aminolipid (AL2), two unknown phospholipids and an unknown aminophospholipid as predominant compounds, but they could be distinguished by the presence of two hydrophilic lipids in strain $1(\mathrm{~W} 3 / 01)^{\mathrm{T}}$; an unknown aminoglycolipid and an unknown aminophosphoglycolipid. Similar, but not identical, profiles were detected for A. pyogenes DSM $20630^{\mathrm{T}}$ and A. haemolyticum DSM $20595^{\mathrm{T}}$ (results not shown).

Analyses of quinones were performed as described previously (Altenburger et al., 1996). Strain $1(\mathrm{~W} 3 / 01)^{\mathrm{T}}$ exhibited a quinone system with menaquinone $\mathrm{MK}-10\left(\mathrm{H}_{4}\right)$ as the predominant compound $(98 \%)$ and MK- $9\left(\mathrm{H}_{4}\right)(2 \%)$.
A similar quinone system, with MK-10 $\left(\mathrm{H}_{4}\right)(91 \%)$ and MK-9 $\left(\mathrm{H}_{4}\right)(9 \%)$, was detected in strain $2(\mathrm{~W} 106 / 04)^{\mathrm{T}}$. This result was not in agreement with the previously determined quinone systems of A. haemolyticum, which was reported to contain MK- $9\left(\mathrm{H}_{4}\right)$ as the predominant compound (Collins et al., 1982). Hence, we analysed the quinone system of $A$. haemolyticum DSM $20595^{\mathrm{T}}$ and A. pyogenes DSM $20630^{\mathrm{T}}$. A. haemolyticum DSM $20595^{\mathrm{T}}$ was found to possess a quinone system with MK-9 $\left(\mathrm{H}_{4}\right)$ as the predominant compound $(85 \%)$ and minor amounts of MK- $8\left(\mathrm{H}_{4}\right)(15 \%)$. In contrast, A. pyogenes DSM $20630^{\mathrm{T}}$, which is the closest phylogenetic relative of strains $1(\mathrm{~W} 3 / 01)^{\mathrm{T}}$ and $2(\mathrm{~W} 106 / 04)^{\mathrm{T}}$, also contained a quinone system with the major compounds MK$10\left(\mathrm{H}_{4}\right)(85 \%)$ and MK-9 $\left(\mathrm{H}_{4}\right)(15 \%)$. The results from the quinone analyses reflect the phylogenetic relatedness of strains $1(\mathrm{~W} 3 / 01)^{\mathrm{T}}$ and $2(\mathrm{~W} 106 / 04)^{\mathrm{T}}$ to A. pyogenes DSM $20630^{\mathrm{T}}$ and clearly distinguish them from the type species of the genus, A. haemolyticum.

\section{Taxonomic considerations}

$16 \mathrm{~S}$ rRNA gene sequence analyses and the chemotaxonomic characteristics of the isolates suggest the assignment of strains $1(\mathrm{~W} 3 / 01)^{\mathrm{T}}$ and $2(\mathrm{~W} 106 / 04)^{\mathrm{T}}$ to the genus Arcanobacterium. Unique physiological profiles and genomic fingerprints and characteristic fatty acid and polar lipid profiles demonstrate that strains $1(\mathrm{~W} 3 / 01)^{\mathrm{T}}$ and $2(\mathrm{~W} 106 / 04)^{\mathrm{T}}$ each represent a separate species within the genus.

In general, the quinone system is a rather conserved characteristic. The finding of MK-10 $\left(\mathrm{H}_{4}\right)$ in one lineage within the genus Arcanobacterium, represented by our isolates and A. pyogenes, is rather exciting because the representative of the second lineage, A. haemolyticum, is characterized by the MK-9 $\left(\mathrm{H}_{4}\right)$ quinone system. Hence, both quinone system and phylogeny indicate a subdivision within the genus Arcanobacterium, and a restriction of the genus to the species A. haemolyticum, A. phocae, A. pluranimalium and 
Table 1. Biochemical characteristics of Arcanobacterium species

Species/strains: 1, A. bernardiae DSM $9152^{\mathrm{T}}$; 2, A. haemolyticum DSM $20595^{\mathrm{T}}$; 3, A. hippocoleae DSM $15539^{\mathrm{T}}$; 4, A. pluranimalium DSM $13483^{\mathrm{T}}$; 5, A. phocae DSM $10002^{\mathrm{T}}$; 6, A. pyogenes DSM $20630^{\mathrm{T}} ; 7$, A. bialowiezense sp. nov. $(n=4) ; 8$, A. bonasi sp. nov $(n=9)$. + , Positive; $\mathrm{W}$, weakly positive; - , negative; $\mathrm{V}(+)$, type strain shows positive reaction; $\mathrm{V}(-)$, type strain shows negative reaction. All strains are positive for D-glucose; all strains are negative for reduction of nitrate, urease, lipase (C14), valine arylamidase, cystine arylamidase, $\alpha$-chymotrypsin, acid phosphatase, naphthol-AS-BI-phosphohydrolase and $\alpha$-mannosidase.

\begin{tabular}{|c|c|c|c|c|c|c|c|c|}
\hline Characteristic & 1 & 2 & 3 & 4 & 5 & 6 & 7 & 8 \\
\hline$N$-Acetyl- $\beta$-glucosaminidase & - & + & + & W & - & $\mathrm{W}$ & - & - \\
\hline Adonitol & - & - & - & - & - & - & $\mathrm{V}(-)$ & $\mathrm{w}$ \\
\hline Alkaline phosphatase & - & + & + & - & + & - & - & - \\
\hline D-Arabitol & - & $\mathrm{w}$ & - & - & - & - & $\mathrm{V}(-)$ & + \\
\hline L-Arabitol & - & - & - & - & - & - & $\mathrm{V}(-)$ & + \\
\hline Catalase & - & - & - & + & - & - & - & - \\
\hline Erythritol & - & - & - & - & - & - & - & $\mathrm{W}$ \\
\hline Esterase (C4) & - & - & - & - & - & - & + & + \\
\hline Esterase lipase (C8) & - & - & - & - & - & - & + & + \\
\hline D-Fructose & - & - & - & - & - & - & + & + \\
\hline$\alpha$-Galactosidase & - & - & - & - & + & - & - & - \\
\hline$\beta$-Galactosidase & - & + & + & - & + & + & - & - \\
\hline Gelatin hydrolysis & - & - & - & + & - & + & - & - \\
\hline$\alpha$-Glucosidase & + & + & + & - & - & + & + & - \\
\hline$\beta$-Glucosidase & - & - & - & $\mathrm{W}$ & $\mathrm{W}$ & - & - & - \\
\hline$\beta$-Glucuronidase & - & $\mathrm{W}$ & + & + & - & + & + & + \\
\hline Glycerol & - & - & - & - & - & - & $\mathrm{V}(+)$ & $\mathrm{W}$ \\
\hline Glycogen & $\mathrm{W}$ & - & - & - & + & $\mathrm{W}$ & - & - \\
\hline D-Lactose & - & + & + & - & $\mathrm{W}$ & + & - & $\mathrm{W}$ \\
\hline Leucine arylamidase & - & - & - & - & + & + & + & $\mathrm{W}$ \\
\hline D-Maltose & + & + & - & $\mathrm{W}$ & $\mathrm{W}$ & + & $\mathrm{V}(-)$ & $\mathrm{W}$ \\
\hline D-Mannitol & - & - & - & - & $\mathrm{W}$ & - & - & - \\
\hline Pyrazinamidase & + & + & - & - & - & - & + & - \\
\hline Pyrrolidonyl arylamidase & $\mathrm{W}$ & $\mathrm{W}$ & - & - & $\mathrm{W}$ & + & - & + \\
\hline D-Ribose & + & + & - & + & + & + & - & - \\
\hline Sucrose & - & $\mathrm{W}$ & - & - & - & $\mathrm{W}$ & - & - \\
\hline Trypsin & - & - & - & - & - & - & $\mathrm{v}(+)$ & + \\
\hline D-Xylose & - & - & - & - & W & + & - & - \\
\hline
\end{tabular}

A. hippocoleae might be desirable. This would lead to $A$. pyogenes, A. bernardiae and the two novel species described in this study being reclassified as a novel genus. In a reclassified genus Arcanobacterium, the presence of a MK$9\left(\mathrm{H}_{4}\right)$ quinone system might be a genus-specific trait, while MK-10 $\left(\mathrm{H}_{4}\right)$ might characterize the neighbouring genus. However, the suitability of the quinone system as the basis for such differentiation would have to be substantiated by examination of all species of Arcanobacterium.

Since the presence of MK-9 $\left(\mathrm{H}_{4}\right)$ is listed as a characteristic trait of the genus Arcanobacterium (Collins et al., 1982), the description of the genus has to be emended to include the presence of MK-10 $\left(\mathrm{H}_{4}\right)$.

\section{Emended description of the genus Arcanobacterium Collins et al. 1983}

In contrast to the original description of the genus, some species do not contain a quinone system with menaquinone MK- $9\left(\mathrm{H}_{4}\right)$ as the major compound; MK- $10\left(\mathrm{H}_{4}\right)$ can also predominate. Other characteristics of the genus are as given by Collins et al. (1982).

\section{Description of Arcanobacterium bialowiezense sp. nov.}

Arcanobacterium bialowiezense (bi.a.lo.wi.e.zen'se. N.L. neut. adj. bialowiezense pertaining to Bialowieza, Poland, where the type strain was isolated).

Cells are short pleomorphic rods that stain Gram-positive. After $48 \mathrm{~h}$ of growth under aerobic conditions on sheep blood agar, colonies are translucent, convex, approx. $0.5 \mathrm{~mm}$ in diameter and surrounded by a narrow zone of $\beta$-haemolysis. Cells are non-motile (motility agar), facultatively anaerobic and are catalase- and oxidase-negative. Best growth occurs at $37^{\circ} \mathrm{C}$; no growth at $42^{\circ} \mathrm{C}$. No growth is observed on Gassner or MacConkey agar. Other physiological and biochemical characteristics are summarized in Table 1 . The quinone system contains $\mathrm{MK}-10\left(\mathrm{H}_{4}\right)$ as the predominant compound. Diphosphatidylglycerol is predominant in the polar lipid profile. Phosphatidylglycerol, three unknown phosphoglycolipids, two unknown aminolipids, two unknown phospholipids, an unknown aminophospholipid, an unknown aminoglycolipid and an unknown aminophosphoglycolipid are present in moderate to minor amounts. The fatty acid profile consists predominantly of unbranched acids with the major compounds $\mathrm{C}_{16: 0}$, $\mathrm{C}_{18: 1} \omega 9 c, \mathrm{C}_{18: 0}$ and $\mathrm{C}_{14: 0}$. Complete fatty acid profiles are listed in Table 2.

The type strain, strain $1(\mathrm{~W} 3 / 01)^{\mathrm{T}}\left(=\mathrm{DSM} 17162^{\mathrm{T}}=\mathrm{NCTC}\right.$ $\left.13354^{\mathrm{T}}\right)$, was isolated from the prepuce of a European bison.

\section{Description of Arcanobacterium bonasi sp. nov.}

Arcanobacterium bonasi [bo.na'si. L. gen. n. bonasi of the European bison (Bison bonasus) from which the type strain was isolated].

Cells are short pleomorph rods that stain Gram-positive. After $48 \mathrm{~h}$ of growth under aerobic conditions on sheep blood agar, colonies are translucent, convex, approx. $0.5 \mathrm{~mm}$ in diameter and surrounded by a narrow zone of $\beta$-haemolysis. Cells are non-motile (motility agar), facultatively anaerobic and catalase- and oxidase-negative. Best growth occurs at $37^{\circ} \mathrm{C}$; no growth at $42^{\circ} \mathrm{C}$. No growth is observed on Gassner or MacConkey agar. Other physiological and biochemical characteristics are summarized in Table 1. The quinone system contains $\mathrm{MK}-10\left(\mathrm{H}_{4}\right)$ as the predominant compound. Diphosphatidylglycerol is predominant in the polar lipid profile. Phosphatidylglycerol, three unknown phosphoglycolipids, an unknown aminolipid, two unknown phospholipids and an unknown 
Table 2. Fatty acid content (\%) of Arcanobacterium strains

Summed feature 3 contains $\mathrm{C}_{16: 1} \omega 7 c / \mathrm{C}_{15}$ iso $2-\mathrm{OH}$; summed feature 5 contains $\mathrm{C}_{18: 2} \omega 6,9 c / \mathrm{C}_{18: 0}$ ante.

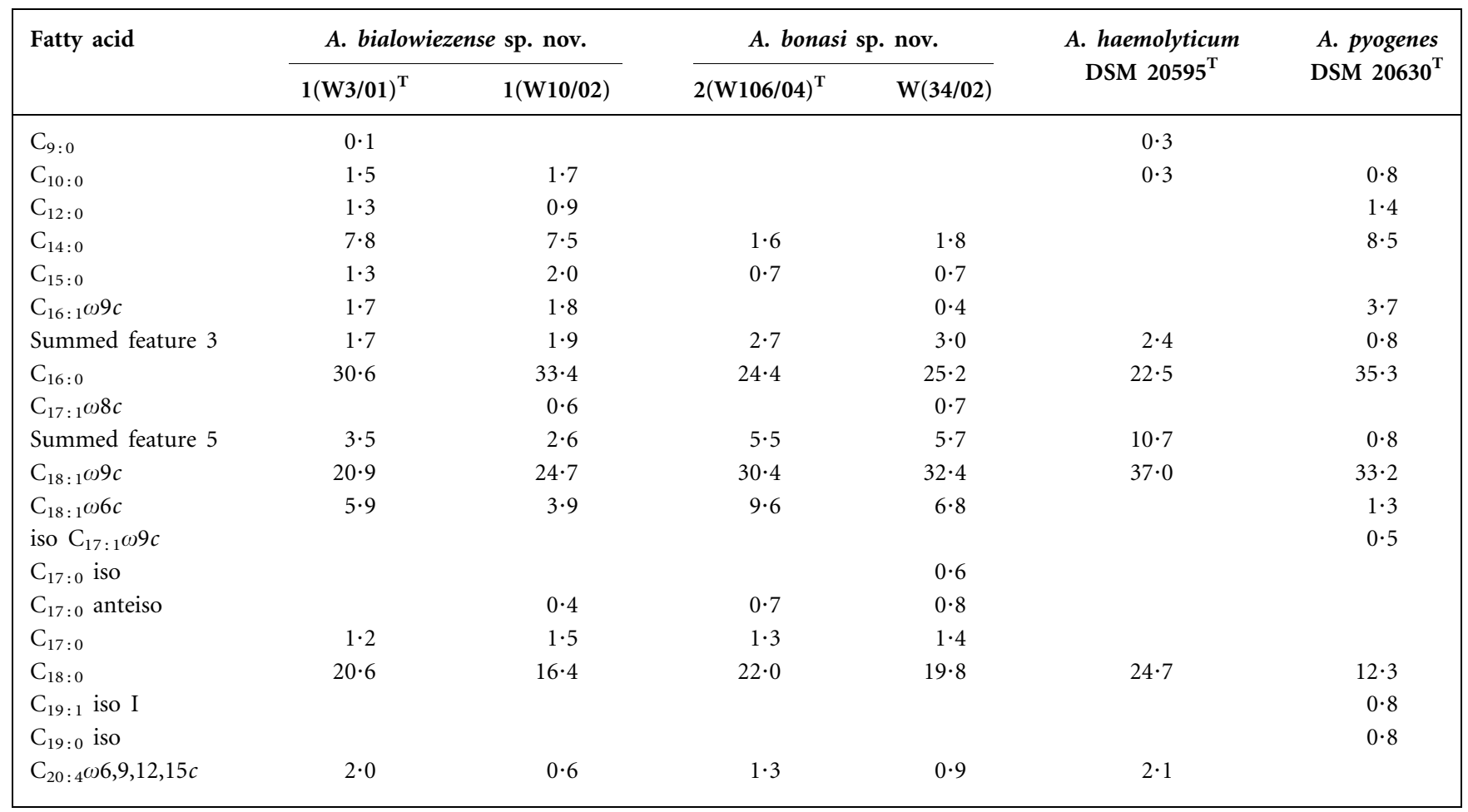

aminophospholipid are present in moderate to minor amounts. The fatty acid profile consists predominantly of unbranched acids with the major compounds $\mathrm{C}_{16: 0}$, $\mathrm{C}_{18: 1} \omega 9 c$ and $\mathrm{C}_{18: 0}$. Complete fatty acid profiles are listed in Table 2.

The type strain, strain $2(\mathrm{~W} 106 / 04)^{\mathrm{T}}\left(=\mathrm{DSM} 17163^{\mathrm{T}}=\right.$ NCTC $13355^{\mathrm{T}}$ ), was isolated from the prepuce of a European bison.

\section{Acknowledgements}

We are grateful to the Stiftung für Deutsch-Polnische Zusammenarbeit, the Frankfurt Zoological Society, the Wittig'sche Stiftung für Menschen und Tiere in Notsituationen and the Zoological Garden, Berlin, for financial support. We thank Jean Euzéby for his help with the correct etymology of the specific epithets. We also thank the National Park Bialowieza and colleagues from the MRI PAS for help in collecting samples.

\section{References}

Altenburger, P., Kämpfer, P., Makristathis, A., Lubitz, W. \& Busse, H.-J. (1996). Classification of bacteria isolated from a medieval wall painting. J Biotechnol 47, 39-52.

Bernard, K. A., Bellefeuille, M. \& Ewan, E. P. (1991). Cellular fatty acid composition as an adjunct to the identification of asporogenous, aerobic Gram-positive rods. J Clin Microbiol 29, 83-89.

Brosius, J., Palmer, M. L., Kennedy, P. J. \& Noller, H. F. (1978). Complete nucleotide sequence of a $16 \mathrm{~S}$ ribosomal RNA gene from Escherichia coli. Proc Natl Acad Sci U S A 75, 4801-4805.
Collins, M. D., Jones, D. \& Schofield, G. M. (1982). Reclassification of 'Corynebacterium haemolyticum' (MacLean, Liebow \& Rosenberg) in the genus Arcanobacterium gen. nov. as Arcanobacterium haemolyticum nom. rev., comb. nov. J Gen Microbiol 128, 1279-1281.

Collins, M. D., Jones, D. \& Schofield, G. M. (1983). Arcanobacterium haemolyticum nom. rev., comb. nov. In Validation of the Publication of New Names and New Combinations Previously Effectively Published Outside the IJSB, List no. 10. Int J Syst Bacteriol 33, 438-440.

Jakob, W., Schröder, H. D., Rudolph, M., Krasinski, Z. A., Krasinska, M., Wolf, O., Lange, A., Cooper, J. E. \& Frölich, K. (2000). Necrobacillosis in free-living male European bison in Poland. $J$ Wildl Dis 36, 248-256.

Kämpfer, P. \& Kroppenstedt, R. M. (1996). Numerical analysis of fatty acid patterns of coryneform bacteria and related taxa. Can J Microbiol 42, 989-1005.

Kämpfer, P., Buczolits, S., Albrecht, A., Busse, H.-J. \& Stackebrandt, E. (2003). Towards a standardized format for the description of a novel species (of an established genus): Ochrobactrum gallinifaecis sp. nov. Int J Syst Evol Microbiol 53, 893-896.

Kita, J., Dziaba, K., Piusinski, W. \& 8 other authors (1994). Preliminary studies on the diagnosis of a disease of the genital organs of male European bison in the Bialowieza Forest of Poland. IUCN Species Surviv Comm Vet Spec Group Newsl 8, 8-9.

Kumar, S., Tamura, K., Jakobsen, I. B. \& Nei, M. (2001). MEGA2: molecular evolutionary genetics analysis software. Bioinformatics 17, 1244-1245.

Louws, F. J., Fulbright, D. W., Stephens, C. T. \& de Bruijn, F. J. (1994). Specific genomic fingerprints of phytopathogenic Xanthomonas and Pseudomonas pathovars and strains generated with repetitive sequences and PCR. Appl Environ Microbiol 60, 2286-2295.

Pearson, W. R. \& Lipman, D. J. (1988). Improved tools for biological sequence comparison. Proc Natl Acad Sci U S A 85, 2444-2448. 
Quinn, P. J., Carter, M. E., Markey, B. \& Carter, G. R. (2000). Clinical Veterinary Microbiology. London: Mosby.

Ventosa, A., Marquez, M. C., Kocur, M. \& Tindall, B. J. (1993). Comparative study of "Micrococcus sp." strains CCM 168 and CCM 1405 and members of the genus Salinicoccus. Int J Syst Bacteriol 43, $245-248$.
Wyss, C., Choi, B. K., Schupbach, P., Guggenheim, B. \& Göbel, U. B. (1996). Treponema maltophilum sp. nov., a small oral spirochete isolated from human periodontal lesions. Int J Syst Bacteriol 46, 745-752.

Ziemke, F., Höfle, M. G., Lalucat, J. \& Rosselló-Mora, R. (1998). Reclassification of Shewanella putrefaciens Owen's genomic group II as Shewanella baltica sp. nov. Int J Syst Bacteriol 48, 179-186. 